\title{
Savremena umjetnost i pitanje medija poslije 11/9 O
}

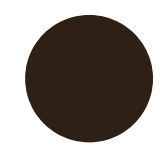

Contemporary Art and the Media after 9/11 
PRETHODNO PRIOPĆENJE

Predan: 4.2.2018.

Prihvaćen: 21.5.2018.

DOI: $10.31664 / z u .2018 .102 .04$

UDK: [07+7.038]:323.28"20"

SAŽETAK

Rušenje njujorških tornjeva 2001. godine i izravni prijenos tog događaja diljem planete unio je novu paradigmu ratovanja putem medija. Vremenski razmak između prvog i drugog udara u WTC pokazao se kao povoljan trenutak za kamermane i fotografe da instaliraju svoju tehniku kako bi gledaocima kod udara drugog aviona omogućili emitovanje slike uživo. Uznemirujuće slike u rekordnom su roku obišle svijet, a njihov karakter iz dokumentarnog prerastao je u simbolički. Došlo je do hipertrofije značenja koja je vodila ka slikovnoj produkciji kodiranoj eksplicitnim sadržajima nasilja i traume. Novonastali medijski ambijent obrazovao je nove mentalitete gledanja i novu vizualnu pismenost. Umjetnost koja nastaje u periodu od 11. septembra 2001. godine naovamo indikator je novog društvenog poretka koji je slikama dao brutalnu moć stvarnog.

Cilj ovog teksta je da detektira neke primjere iz savremene umjetničke produkcije-prvenstveno radove Hansa Petera Feldmanna, Douga Ashforda, Francisa Alÿsa, Thomasa Hirschorna i Munira Fatmija-i da na njima načini svojevrsnu analizu fenomena gdje savremene umjetničke prakse obrađuju pitanja koja je nametnula postseptembarska slikovna erupcija. Pritom se umjetnički radovi navedenih umjetnika koriste kao primarni izvor u artikuliranju perspektive boljeg razumijevanja nove uloge medija.

KLJUČNE RIJEČI

terorizam, nasilje, umjetnost, slika, mediji, televizija, New York, WTC
PRELIMINARY PAPER

Received: February 4, 2018

Accepted: May 21, 2018

DOI: 10.31664/zu.2018.102.04

UDC: $[07+7.038]: 323.28 " 20 "$

\section{SUMMARY}

The collapse of the Twin Towers in 200I and its direct transmission around the globe introduced a new paradigm in warfare conducted through the media. The time span between the first and the second attack on WTC was a suitable moment for the cameramen and photographers to install their equipment and make it possible for the viewers to watch the second airplane crushing into the towers live. The disturbing images travelled around the world in no time, and their character shifted from documentary to symbolical. The resulting hypertrophy of meaning led to an image production encoded with the explicit content of violence and trauma. The newly created media setting generated new viewing mentalities and new visual literacy. Art produced in the period since September II, 200I has been an indicator of the new social order, which endows images with the brutal power of reality.

The aim of this paper is to present some examples from the contemporary artistic production-primarily works of Hans Peter Feldmann, Doug Ashford, Francis Alÿs, Thomas Hirschorn, and Munir Fatmi-and to perform an analysis of the way in which the contemporary art practices deal with the issues imposed by the post-September eruption of images. The works of the said artists have thereby been used as primary sources in articulating a perspective that will lead to a better understanding of the new role of the media.

\section{KEYWORDS}

terrorism, violence, art, image, media, television, New York, WTC

\section{Irfan Hošić}




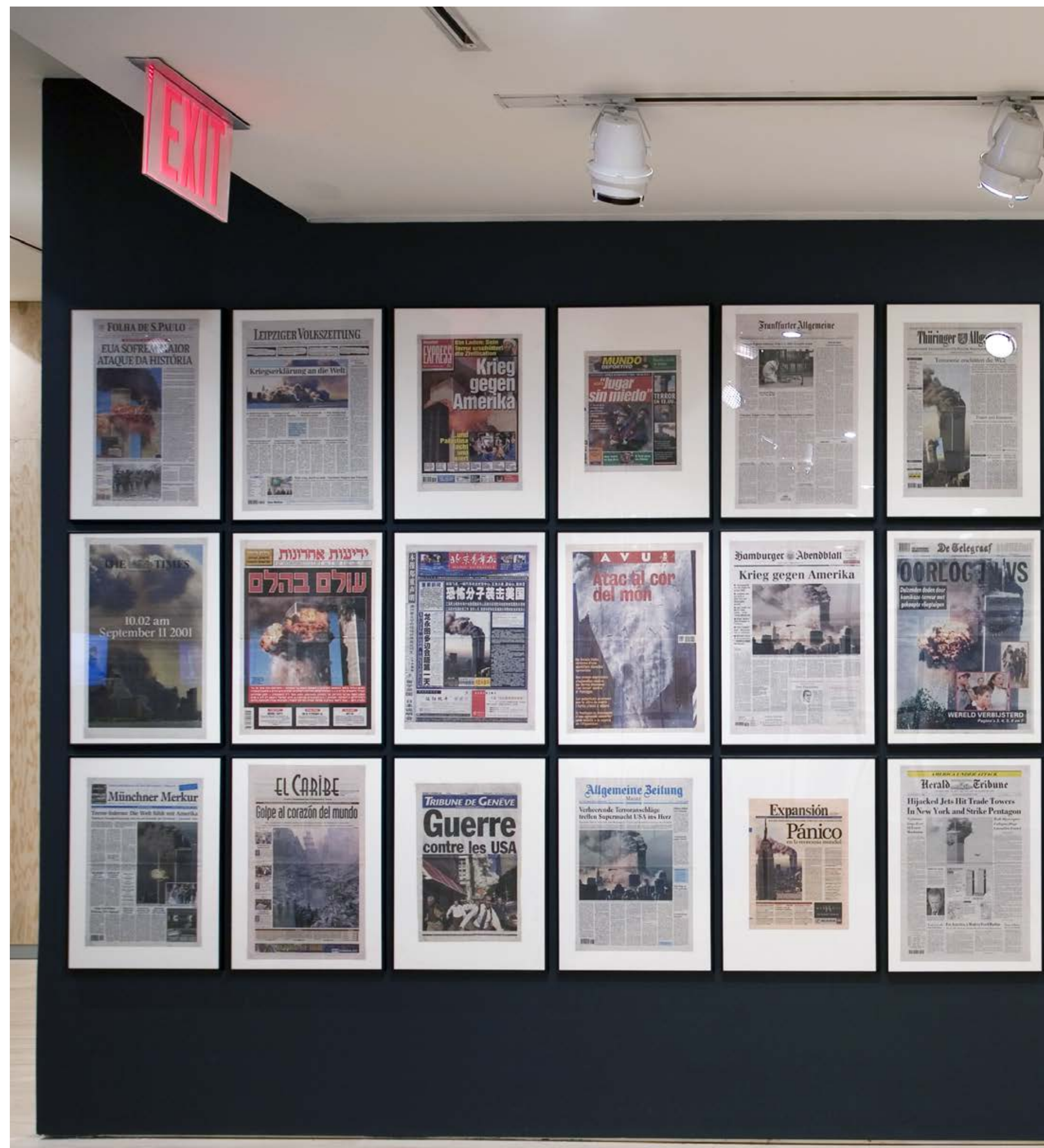



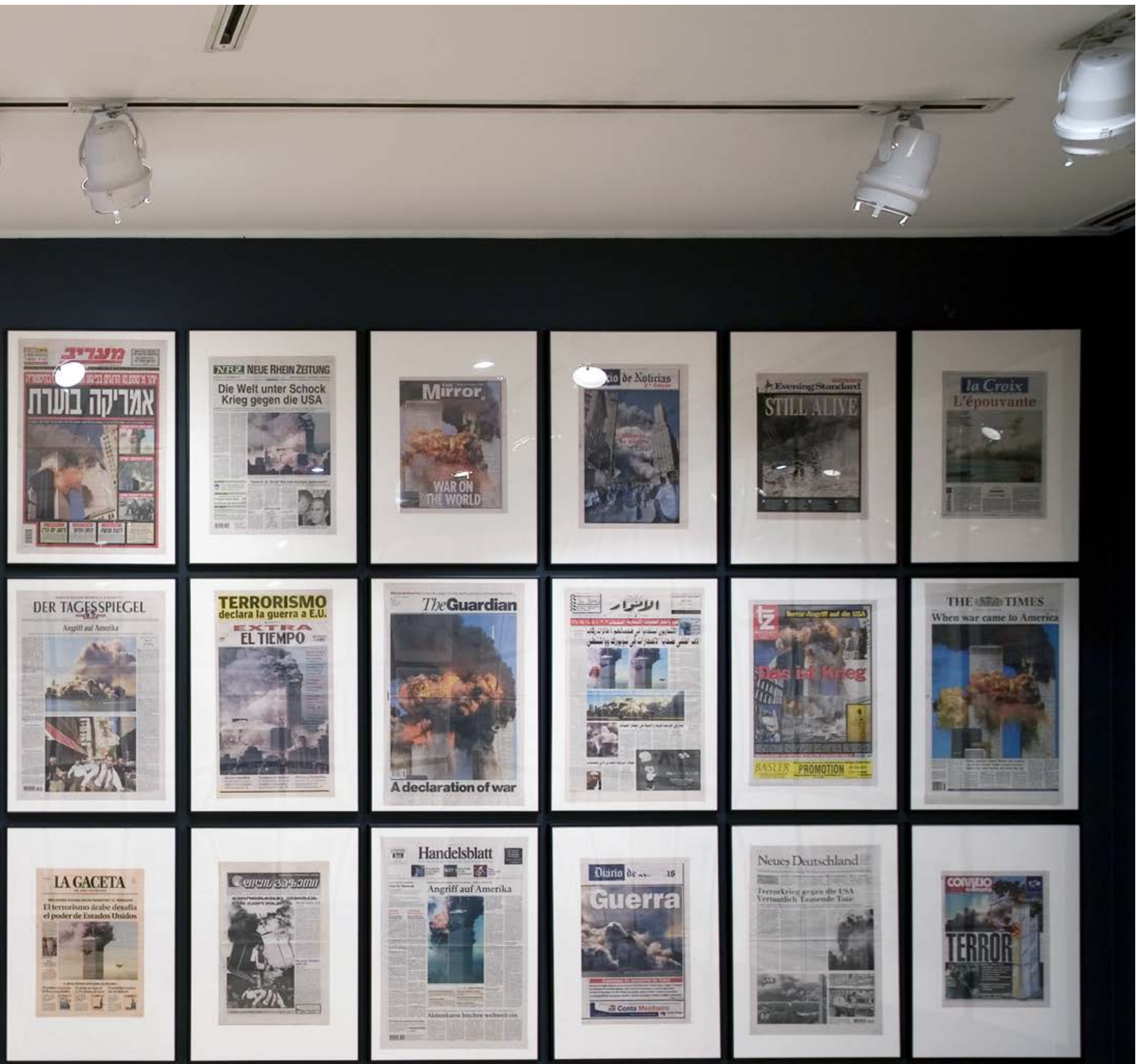

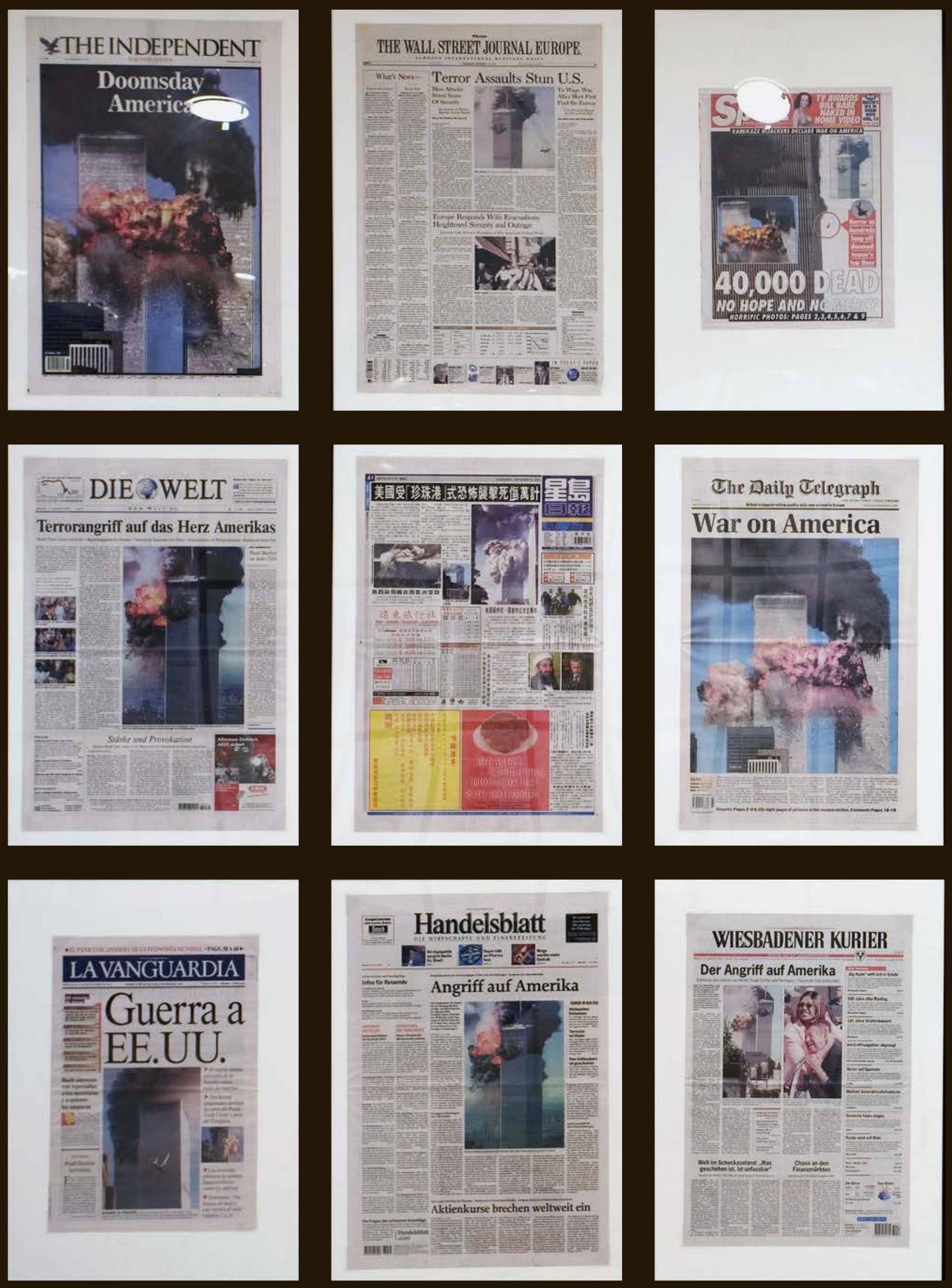


\section{Zleuf:Grevenbroicher zeitung}

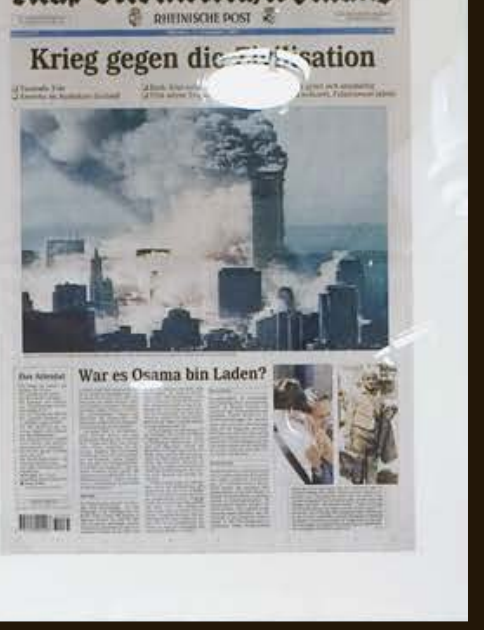

\section{Siiddeutsche Zeitung}

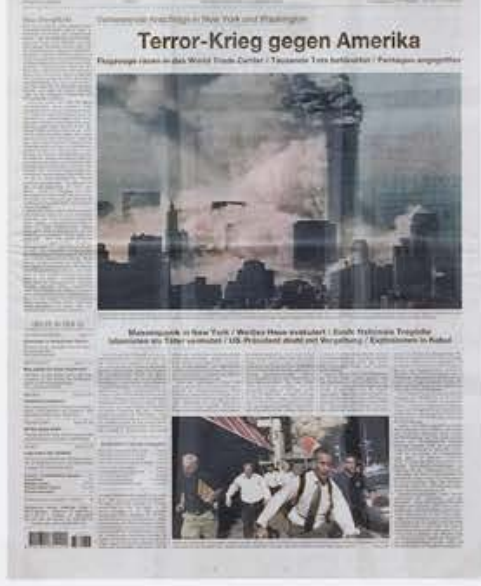

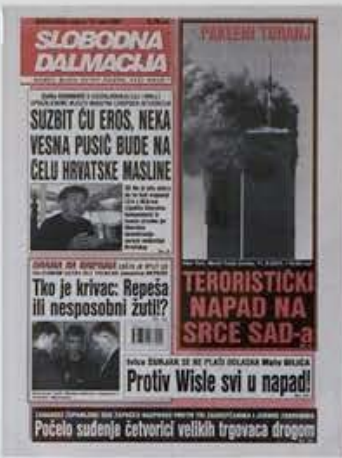

THE IRISH TIMES IIII Prtack on Amorica | If

World in shock as Bush vows terror will not defeat freedom

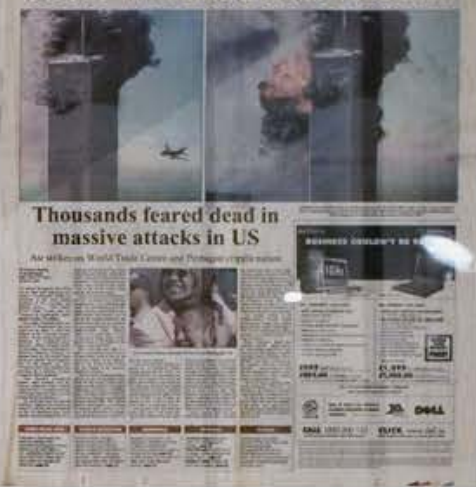

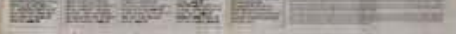
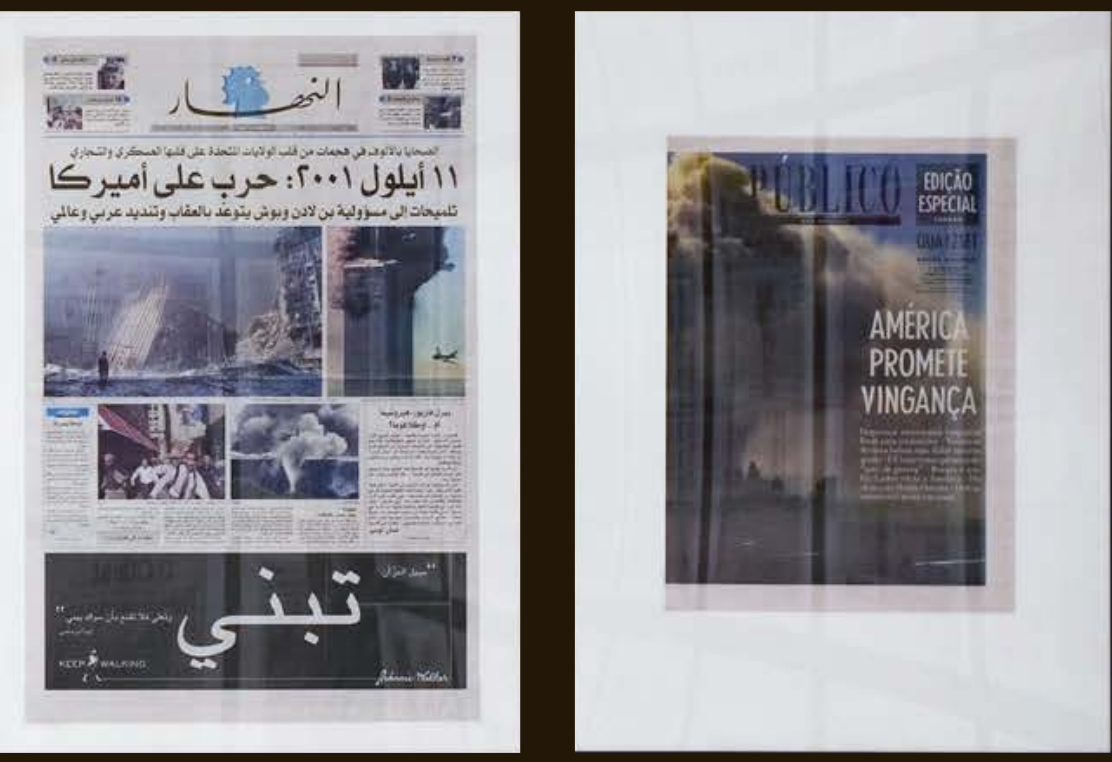

\section{T. DIE PWELT}
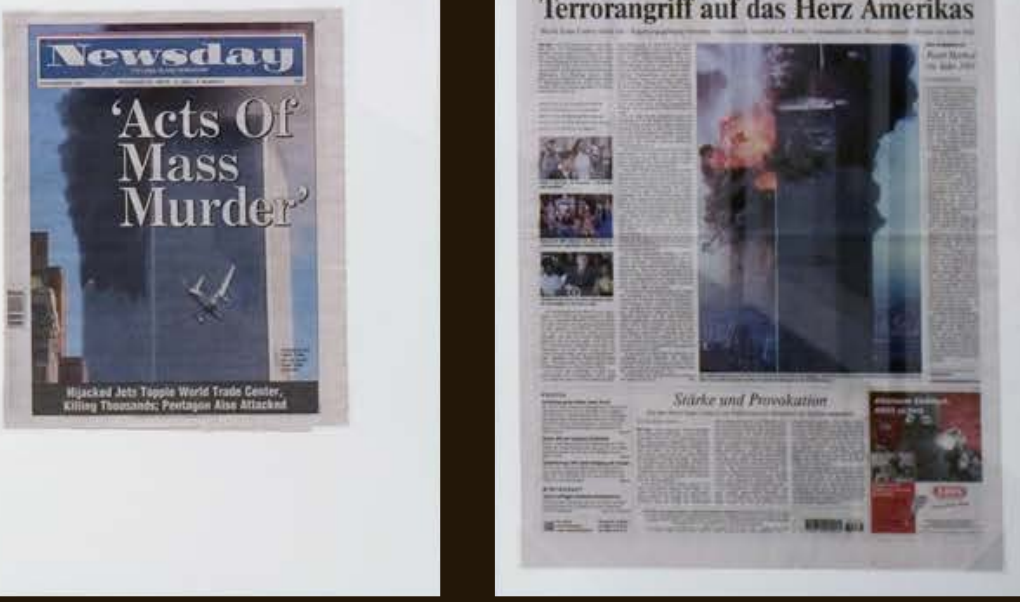

Terrorangriff auf das Herz Amerikas

L'Amérique frappée au cœur

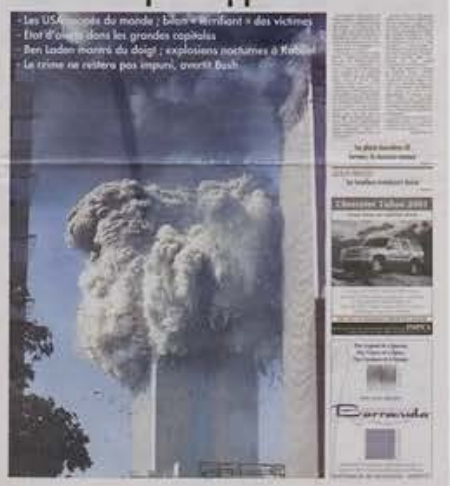




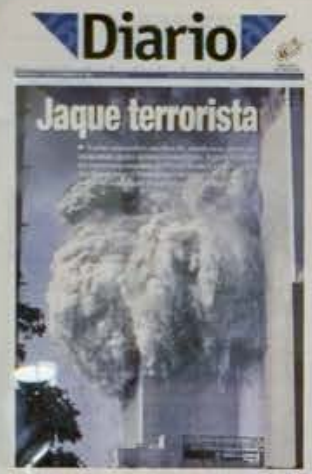

[E ma" 24 DRB

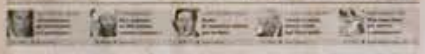

20mila morti a Manhattan

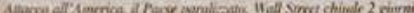

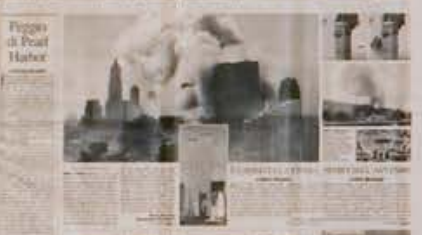

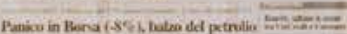

国

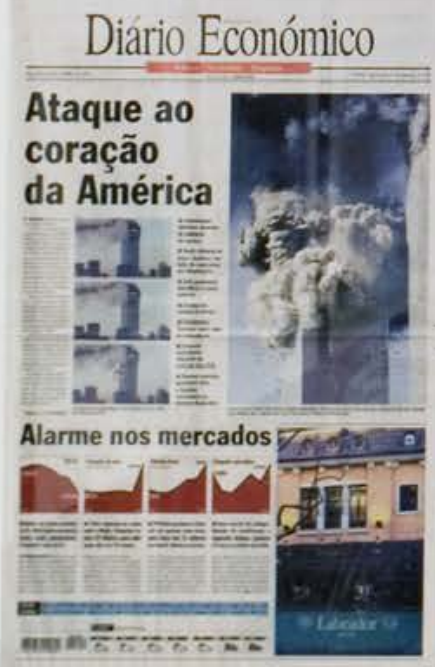

NeueWestâlische
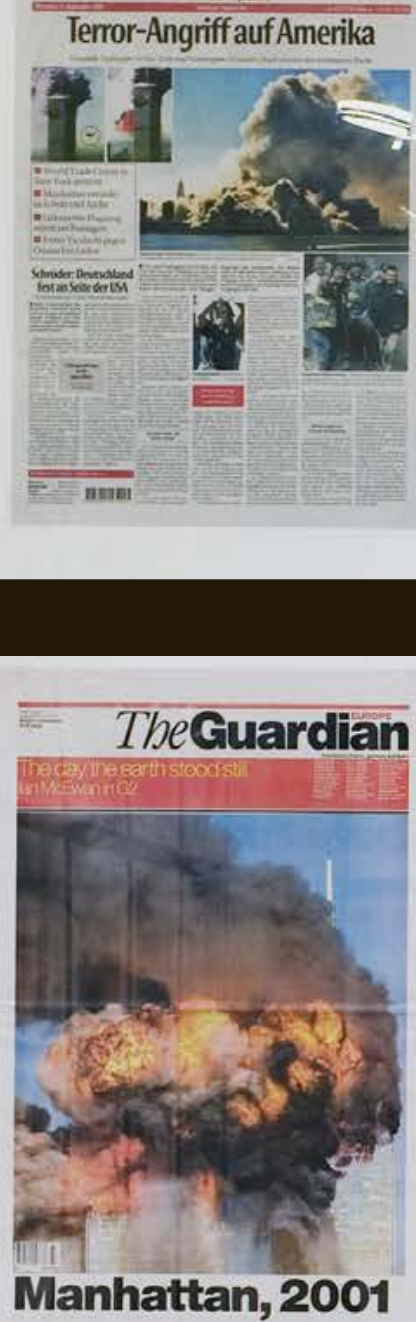

I- Aachener Nachrichten

틀 틀

Amerika trauert um Tausende

Opfer und jagt die Terroristen

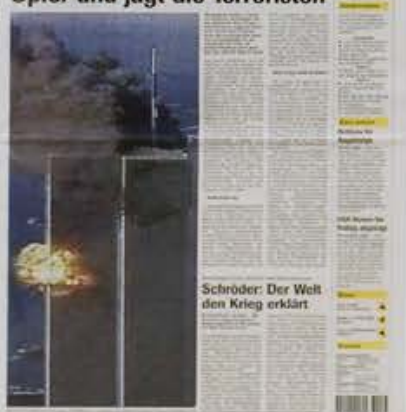

THE WALL STREET JOURNAL EUROPR

Whas Xer- Terror Assaults Stun U.S.

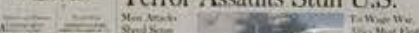

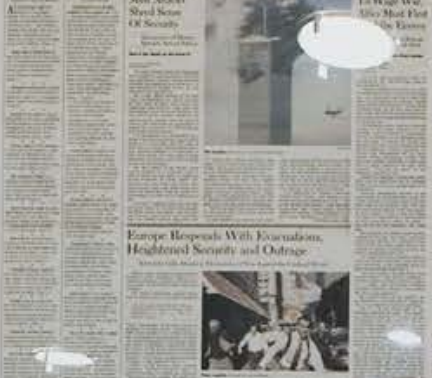
ardis

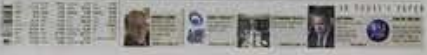

\section{T/terald Eribune}

Hijacked Jets Hit Trade Towers In N.Y. and Plow Into Pentagon

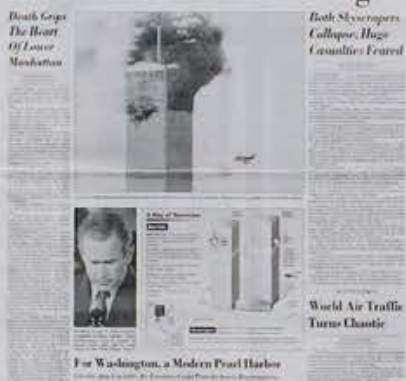

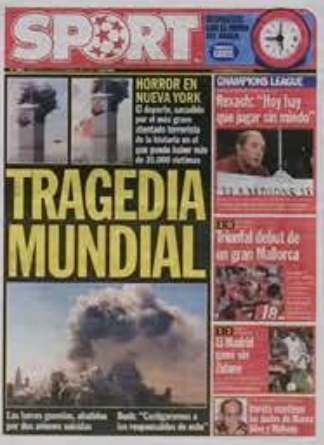




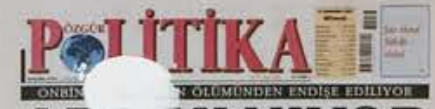
ABL YANIYOR

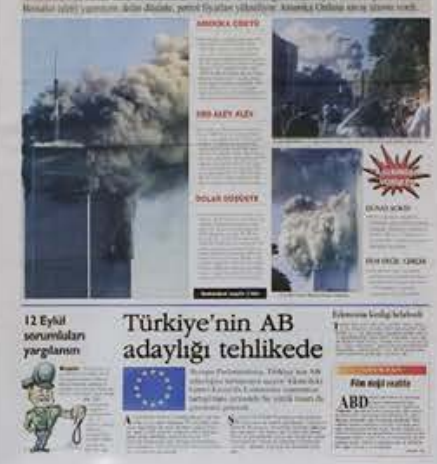

19. NU'P TRGER

Die Welt steht unterSehock

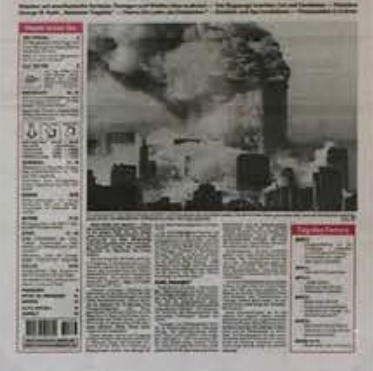

EVRENSEL

\section{sonums}

21 yıllık yıkım ${ }_{\substack{\text { kadidecegiz' } \\ \text { kanuma }}}$

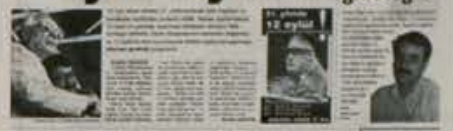

TÜMTis'le büyük dayanısma

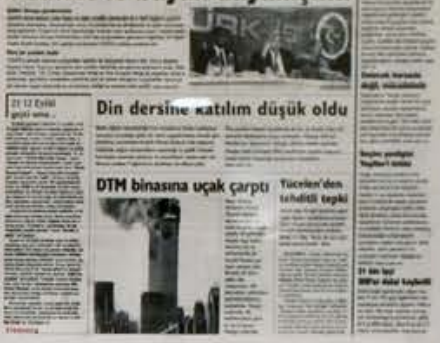

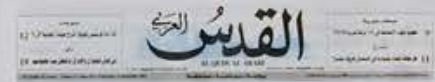

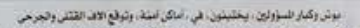

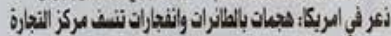

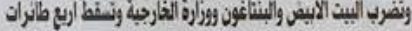

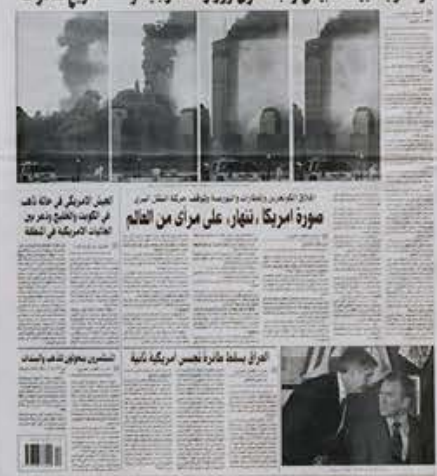

IIIII

$=$
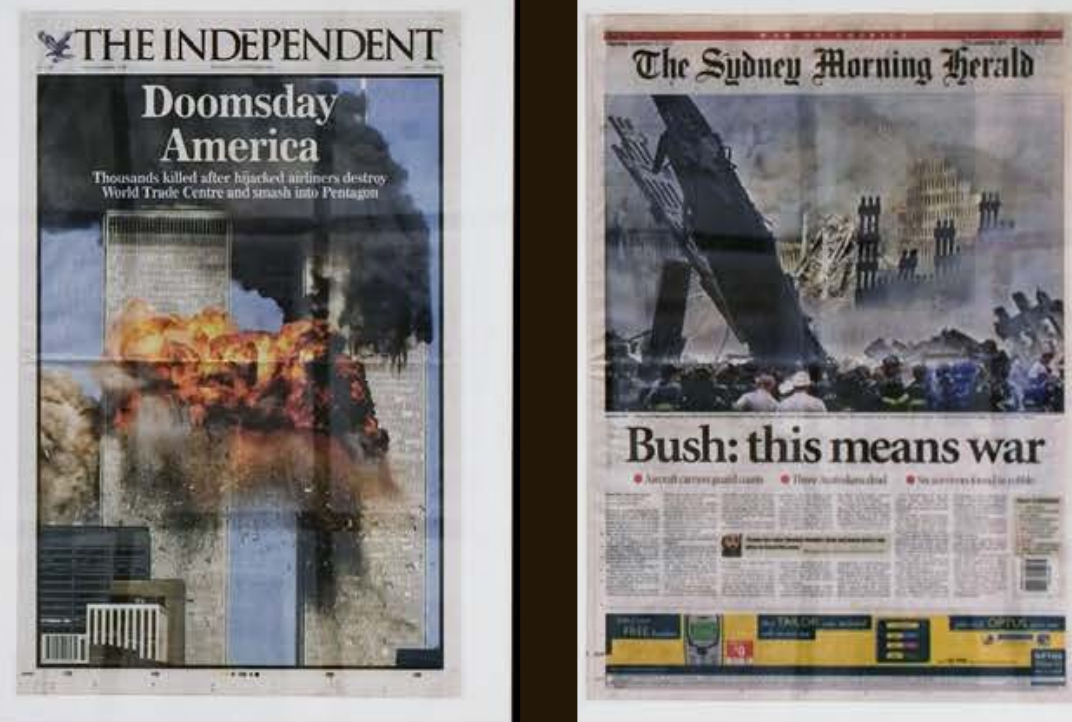

Bush: this means war
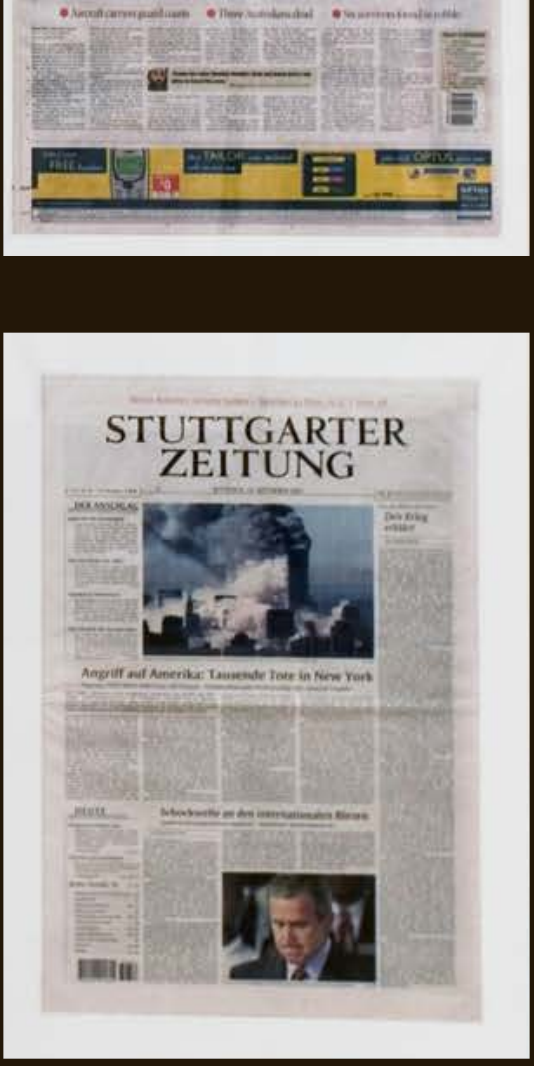
Rad njemačkog umjetnika Hansa Petera Feldmanna pod nazivom 9/12 Frontpage iz 2001. godine otvara nekoliko kritičkih pitanja o karakteru, značaju i ulozi medija u prizmi rušenja njujorških blizanaca. Rad je kreiran od naslovnih stranica novina iz cijelog svijeta a koje su objavljene dan poslije rušenja WTC-a. Premda na svim naslovnicama dominira prikaz rušenja tornjeva, umjetnik kroz naziv rada inicira novo čitanje sadržaja koji je vezan uz postseptembarsku eru u prizmi složene uloge novinarstva i medija uopće. Odnos naslova, podnaslova i fotografije napadnutih tornjeva, te količina prostora posvećena tom događaju na naslovnim stranicama svjetskih dnevnih novina, daje uvid u karakter žurnalizma koji je nastao na ruševinama njujorške tragedije. Međusobna usklađenost naslovnih stranica unatoč njihovom pripadanju različitim jezicima ukazuje na zastrašujuće aspekte monopolizacije i industrijalizacije novinskih agencija na globalnom nivou. Činjenica da se novine, magazini, televizijski i radijski kanali, izdavači, novinske agencije, filmska studija i internetske usluge nalaze u vlasništvu tek nekoliko tvrtki, navodi na zaključak o medijskoj nadmoći u kontrolisanju i kanalisanju javnog mišljenja putem masovnih medija.

Navedeni Feldmannov rad uklapa se u njegov strastveni odnos prema slikama i vizualnim artefaktima vremena u kojem djeluje. Duhovit i ciničan odnos prema slikomaniji 20. i 21. stoljeća postao je okosnicom njegovog umjetničkog promišljanja. Sabiranjem i reasambliranjem efemernih vizualnih referenci, Feldmann kreira nove značenjske kontekste u kojima su pitanje umjetničkog autorstva i aproprijacija neki od glavnih problema i strategija. Događaj kao što je napad na Svjetski trgovački centar inicirao je eksplozivnu slikovnu proizvodnju slojevitog i kompleksnog obima, čiji rezultati su se lako uklopili u već definiran umjetnički sustav Hansa Petera Feldmanna. Ovoga puta umjetnik je, dakako, u fokus stavio pitanje značaja žurnalizma u trenucima ekscesa kao što je to bio napad na SAD.

Sutrašnje novine nakon rušenja WTC-a bile su također okosnicom u radu američkog umjetnika Douga Ashforda. lako iz 2015. godine, rad Next Day Page 1 se pored medijske reprezentativnosti ovog događaja referira i na slikarsko naslijeđe američkog apstraktnog ekspresionizma. Ashford naslovnicu novina New York Times od 12. septembra 2001. godine hrabro koristi kao puku podlogu za bespredmetne slikarske intervencije tzv. slikarstva oštrog polja i time kreira neku vrstu alarmirajuće jukstapozicije. Vremenski otklon od više od deset godina kada je rad nastao također je indikativan jer su u tome periodu napravljene neke od najvećih pogreški američke vanjske politike prema zemljama Bliskog i Srednjeg Istoka, čije se posljedice i danas osjećaju, a u čemu su, dakako, sudjelovali i mediji.

Naime, od 11. septembra naovamo izmijenjena je uloga i funkcija novinarstva, a medijska retorika i medijalizacija traumatskih činjenica doprinijela je popularizaciji napada na WTC. Od pada Berlinskog zida pa do rušenja WTC-a vanjskopolitičke redakcije unutar medijskih kuća bilježile su smanjen interes javnosti za međunarodna politička
Work of German artist Hans Peter Feldmann titled $9 / I 2$ Frontpage (200I) raises several critical issues on the nature, significance, and role of the media in the view of attacks on the New York Twin Towers. It consists of newspaper front pages from all over the world, published on the day after the destruction of WTC. Even though these pages are dominated by the image of airplanes crushing into the towers, the artist encourages a new reading of their content, as suggested in his title, linked to the post-September era seen through the prism of the complex role of journalism and the media as such. The relationship between the headlines, subtitles, and photographs of the towers under attack, as well as the space dedicated to the event on the front pages of daily newspapers all around the globe, offers an insight into the nature of journalism grown on the ruins of the New York tragedy. Despite the fact that the newspapers were published in different languages, the uniformity of their front pages points to the terrifying monopolization and industrialization of news agencies on the global level. The fact that the newspapers, magazines, television and radio channels, publishers, news agencies, film studios, and internet providers are owned by a small number of companies speaks of their superior power to control and channel public opinion by means of the mass media.

Feldmann's work reveals his passionate love of images and visual artefacts from his time. His witty and cynical attitude towards the iconomania of the 2oth and 2I st centuries has become the axis of his artistic expression. By collecting and reassembling ephemeral visual references, he has been creating new contexts of meaning, in which artistic authorship and appropriation have been among the main issues and strategies. An event such as the assault on the World Trade Center initiated an explosive visual production of a multi-layered and complex scope, the results of which fitted well into the already defined artistic system of Hans Peter Feldmann. This time, however, the artist naturally focused on the meaning of journalism in excessive moments such as the US attacks. Hess, Kalb, The Media and the War on Terrorism, 1.

Carey, „American journalism on, before and after September 11”, 71-90.

3

Bush, „Address to a Joint Session of Congress and the American People". 
zbivanja, ali „sa jutrom 11. septembra 2001. godine svijet izvan Sjedinjenih Američkih Država postao je jedini pristojan interes ostatku američkog žurnalističkog establišmenta". ${ }^{1}$ Napad na Svjetski trgovački centar promijenio je taj trend, a međunarodnu politiku iznova gurnuo u prvi plan. Sa druge strane, novinarstvo je zloupotrijebljeno kao produžena ruka politike sa svrhom manipulisanja javnosti. ${ }^{2}$ Mediji kao alatke novinarstva stali su na stranu nacionalističke retorike koju je proklamirala aktualna američka administracija, a najkontroverznija izjava američkog predsjednika Georgea W. Busha, „Ili ste sa nama, ili ste sa teroristima”, definirala je novu strategiju američke diplomatije. ${ }^{3}$ Uspostavljen je redefinirani model globalne političke polarizacije po uzoru na hladni rat u drugoj polovini 20. vijeka u kojem je „novi neprijatelj" ostao gotovo nevidljiv.

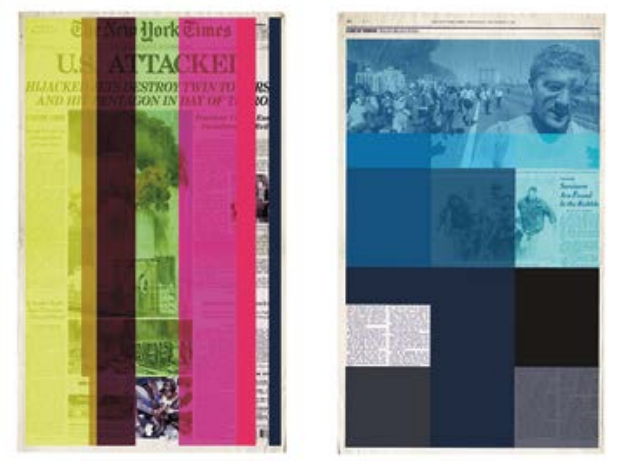

Douglas Ashford, Next Day Page I, 2015. Ljubaznošcu umjetnika / Courtesy of the Artist $\uparrow$

1 Hess, Kalb, The Media and the War on Terrorism, I. 2 Carey, "American Journalism on, before and after September II," $7 \mathrm{I}-90$.

3

Bush, "Address to a Joint Session of Congress and the American People."

4

Paul, Bilder des Krieges - Krieg der Bilder, 439.
The morning papers following the destruction of WTC have also been an inspiration for the American artist Doug Ashford. Even though produced in 20I5, his work Next Day Page I refers both to the representative nature of the event in terms of the mass media and to the painting legacy of American abstract expressionism. Ashford has boldly used the front page of the New York Times from September I2, 20OI as a background for abstract painting interventions of the so-called hard-edge type, creating a sort of alarming juxtaposition. The time lag of more than ten years is also indicative, since that was the period in which some of the worst mistakes were made in American foreign policy regarding the countries of the Middle East, the consequences of which are still felt today and in which the media, of course, played a specific role.

Namely, since that September II, the role and function of journalism have changed, while the media rhetoric and the medicalization of a traumatic fact have contributed to the popularization of the WTC attacks. From the fall of the Berlin Wall to the destruction of the Twin Towers, international editorials within the news agencies suffered a reduced public interest in international politics; however, "by the morning of September II, 200I, the world outside the United States had become of only modest interest to the rest of the American journalist establishment." 1 The WTC attacks inverted this trend and pushed international politics back into the foreground. However, journalism was now being abused as the prolonged arm of politics with the aim of manipulating the public. ${ }^{2}$ The media, as the tools of journalism, took the side of nationalist rhetoric as proclaimed by the current American administration, and the highly controversial statement of President George W. Bush "You are either with us, or with the terrorists" set out the new strategy of American diplomacy. ${ }^{3}$ A new, redefined form of global political polarization was established, modelled upon the Cold War in the second half of the 2oth century, in which the "new enemy" remained almost invisible.

From the perspective of image theory and image analysis, the significance of the Twin Towers attacks and their shocking effect is not in the number of casualties or the extent of material damage. Namely, "the semantic superstructure of events, which seemed rather modest to the historians compared to the bombings of Dresden or Hiroshima with their death-toll of 20000 and 200000 respectively, was primarily constructed by means of real-time images (Echtzeitbilder)." ${ }^{4}$ The shocking effect was achieved by using contrast in the context in which the event had taken place. Two huge passenger airplanes crashing into two monumental architectural columns had a performative structure reminiscent of a classical tragedy, primarily due to its aesthetical dimension. The dramatic contrast was radicalized by the relationship between the act and the place where it happened. For a variety of reasons, New York was a place where something like that was hardly to be expected. Moreover, the perception of New York and the US as the most desirable destination of liberal and open world made the crashing of airplanes into 
Sa aspekta teorije i analize slike, značaj napada na njujorške tornjeve i njihov šokirajući efekat ne leži u broju poginulih ili prouzrokovanoj materijalnoj šteti. Naime, „značenjska nadogradnja događaja, koja se historičarima, zbog komparacije sa napadima na Dresden i Hirošimu sa 20000 odnosno 200000 mrtvih, pokazala prije skromnom, realizirana je, u prvom redu, prije svega posredstvom vremenski autentičnih slika (Echtzeitbilder)". " Šokirajući efekat postignut je posredstvom kontrasta unutar konteksta gdje se događaj desio. Zabijanje ogromnih putničkih aviona u dva megalitna arhitektonska stuba posjeduje performativnu strukturu nalik klasičnoj tragediji prvenstveno zbog estetske dimenzije koja je u njoj sadržana. Dramski kontrast je radikaliziran odnosom čina i mjesta u kojem se događaj zbio. New York je iz niza razumnih razloga mjesto u kojem se takav događaj najmanje očekivao. Isto tako, percepcija New Yorka i Sjedinjenih Američkih Država kao najželjenijih destinacija slobodnoumnog i otvorenog svijeta učinio je zabijanje aviona u WTC iznimno šokirajućim. Uz to, „osjećaj globalnog terorizma izazvan je djelimično osjećajem da je jedina svjetska super-moć, najveća i najsnažnija, odjednom viđena kao ranjiva, što je uzrokovalo osjećaj anksioznosti kod sviju". ${ }^{5} \mathrm{~S}$ obzirom na to da „teroristički napadi uglavnom posjeduju pomno razrađenu koreografiju kako bi privukli pažnju elektronskih medija i međunarodne štampe", efekat katarze u slučaju napada na NYC bio je zagarantovan, a medijski prikaz napravio je od rušenja WTC-a neviđeni performans uzvišenog stila. ${ }^{6}$

U Feldmannovom radu 9/12 Frontpage moguće je rekonstruirati i hipertrofiju značenja određene slike koja nastaje mas-medijskom dostupnošću. U slučaju napada na WTC ta činjenica je očita. Vremenski razmak između prvog i drugog udara omogućio je kamermanima da instaliraju video i foto opremu kako bi prijenos događaja pratili uživo, jer je „vrijeme između neposrednog događaja i slikovnog emitovanja sve kraće ili se čak odvija uživo". ${ }^{7}$ Osim što su zastrašujuće slike u kratkom roku obišle svijet, njihov karakter doživio je nekoliko transformacija na relaciji dokumentarnog i simboličkog. Udarom aviona u WTC ikonična slika njujorškog skylinea prvo je degradirana i spuštena na razinu realnog, da bi posredstvom medija doživjela novi simbolički naboj širokog odjeka. Zahvaljujući medijskoj reproduktibilnosti „ovi događaji su istovremeno radikalizirali odnos slike i realnosti". ${ }^{8}$ Ovdje se misli na učestalo i kontinuirano prikazivanje samog rušenja njujorških tornjeva u masovnim medijima, što je „slikama povratilo brutalnu moć stvarnog". .9 Bilo je gotovo nemoguće da mediji i novinarski aparat spriječe transformaciju dokumentarne slike u simboličku. Naslijeđe tradicije skandala i šoka kao glavnih karakteristika evropske kulturne moderne tokom 19. i 20. vijeka, kao i snažna ikoničnost New Yorka i njegove arhitekture i urbanizma, poslužili su kao platforma izvedbi zaokruženog vizualno-estetskog spektakla. Ne manje važne u tom pravcu su drastične konstatacije da je „ulijetanje aviona u tornjeve Svjetskog trgovačkog centra upotpunjeno umjetničko djelo" ${ }^{10}$ ili da je rušenje WTC-a „najveće umjetničko djelo ikada". ${ }^{11}$ lako radikalne, navedene tvrdnje zasnovane
WTC all the more shocking. Eventually, "the sense of global terror was induced partly with the sense that the world's only superpower, the biggest and strongest, was suddenly seen as vulnerable, creating high anxiety for all.” 5 Regarding the fact that "terrorist attacks are often carefully choreographed to attract the attention of the electronic media and the international press," the catharsis effect in case of NYC attacks was guaranteed, and the media representation turned the destruction of the two towers into an unprecedented and sublimely styled performance. ${ }^{6}$

In Feldmann's artwork 9/I2 Frontpage, one can also reconstruct the hypertrophy of meaning in a specific image, which is due to its accessibility in the mass media. In case of the WTC attacks, this fact is quite evident. The time lag between the two attacks made it possible for the cameramen to install their video and photo equipment in order to cover the event live, for "the time between the reported event and its visual transmission is becoming ever shorter and may sometimes even be real time."7 Besides the fact that the terrifying images reached the whole world in almost no time, they were subjected to several transformations on the relation between the documentary and the symbolical. With the airplane crashing into WTC, the iconic image of the New York skyline was first degraded to the level of reality, only to be charged with a new and extensive symbolic power by the media. Due to their reproducibility in the media, "these events radicalized the relationship between the image and the reality at the same time." 8 This refers to the repeated and continued presentation of the moment in which the towers collapsed in the mass media, which "restored to the images the brutal power of reality." 9 
su na ostvarenju jedinstvenog vizualnog doživljaja koji je u dobroj mjeri bio potpomognut dobro razrađenom medijskom reproduktibilnošću. Napad na WTC je igrokaz skučenog repertoara koji sadrži spomeničku monumentalnost u kojoj pamćenje, sjećanje i komemoracija, tj. predstavljanje i promatranje historijskih događaja zauzimaju važno mjesto. Upravo sa te strane prilazi i Feldmann. Monumentalna instalacija sačinjena od 151 naslovnice ukazuje na polivalentan značaj medijacije prikazivanja historije posredstvom slika. Bez imalo dvojbe, slika napadnutih Blizanaca postala je instant-ikona bespredmetnog spomenika. Ikona, koja mobilizira širok spektar publike i inaugurira novi način zurenja, koji ne traži pažljivo proučavanje ili razmatranje, već posjeduje apsolutnu moć religijske slike (ikone) u kojoj je istina već definirana. Naivni gledalac uzdiže se na najviše hijerarhijsko mjesto na ljestvici promatračā.

5

Sreberny, "Trauma Talk," 225.

6

Weimann, Winn, The Theater of Terror: Mass Media and International Terrorism, $5 \mathrm{I}$.

7

Gehring, "Der Angriff auf das singuläre Bild," I2. 8

Paul, Bilder des Krieges - Krieg der Bilder, 433.

9

Schmitt, "Die Weisse Magie des Kinos und die schwarze Magie des Terrorismus."

10

Žižek, Welcome to the Desert of the Real! Five Essays on September II and Related Dates, II.

11

Stockhausen, "Huuuh!"

12

Werckmeister, “Ästhetik der Apokalypse," 195.

13

Belting, Florenz und Bagdad. Eine westöstliche Geschichte des Blicks, 23. 14

Ibidem.
It was almost impossible for the media and the journalist apparatus to prevent the transformation of documentary images into symbolic ones. The inherited tradition of scandal and shock as the main features of European cultural modernism in the I9th and 2oth centuries, as well as the strongly iconic nature of New York with its architecture and urban structure, served as a platform for performing an all-inclusive visual and aesthetical spectacle. Equally important along this line were the drastic statements that "the planes hitting the WTC towers was the ultimate work of art" 10 or "the greatest work of art imaginable." "Although radical, these statements are based on the accomplishment of a unique visual experience, supported to a considerable extent by well-elaborated media reproducibility. The attack on WTC was a drama with a reduced repertoire and a monumentality in which memory, remembrance, and commemoration, that is, the presentation and viewing of historical events, occupied a prominent place. This is also the perspective taken by Feldmann. His monumental installation consisting of I5I headline pages indicates the polyvalent meaning of mediating historical representation by means of images. Quite obviously, the image of the Twins under attack became the instant icon of a non-figurative monument. An icon that mobilized a broad range of audiences and inaugurated a new way of gazing, which did not require careful study or consideration, but had the absolute power of a religious image (icon), in which truth was already defined. The naïve spectator was thus elevated to the highest hierarchical place on the scale of observers.

Reminiscent of a film scenario in which hijacking airplanes and attacking the most iconic building in the world is attributed to sophisticated aggressors, this event, in its performative aspect, speaks of the spectator, that is, of his culture of spectatorship. "In this way, the images of September II were associated with the imaginary disasters that the visual media culture had made familiar to us much earlier." 12 Namely, Western culture has had a centuries-old tradition of spectatorship; the Renaissance and its inventive use of depth perspective is an illustrative example. When the artist of perspective presented new images to the eyes of the spectators by simulating their view, little was he aware of the revolutionary meaning of this invention for the history of spectatorship. ${ }^{13}$ The "simulation of view" as seen in the linear perspective of Renaissance painting is paradigmatic, since it speaks of the legacy and tradition of modern-day spectators. The image of perspective presents the view of the world according to the same model that the images use today, in the times of the rule of the media. Hans Belting has called that view "iconic" as a gaze that turns into an image ("zum Bild gewordener Blick"). The image of the WTC attacks requires a spectator, since it is articulated only through his gaze. It is a result of the "hungry" eye of the modern spectator. This communication pattern is significant, since what cultures do with their images and the way they reduce the world to images reveals the essence of their thinking. ${ }^{14}$ 
Nalik filmskom scenariju u kojem se otmica aviona i napad na najikoničniju zgradu na svijetu pripisuje sofisticiranim napadačima, ovaj događaj u svome izvedbenom aspektu govori o gledaocu, tj. njegovoj kulturi gledanja. „Na taj način se slike 11. septembra pripajaju imaginarnim katastrofama s kojima nas je vizualna medijska kultura upoznala već mnogo ranije". 12 Naime, Zapadna kultura posjeduje višestoljetnu tradiciju gledanja (spectatorship); primjer renesanse i inventivnog korištenja dubinske perspektive u ovom kontekstu može biti interesantan. Kada je „umjetnik perspektive izložio nove slike očima publike tako što je simulirao njihov pogled", nije ni bio svjestan revolucionarnog značaja ovog pronalaska za historiju gledanja. ${ }^{13}$ "Simulacija pogleda", kako je viđena u primjeru dubinske perspektive renesansnog slikarstva, je paradigmatična jer govori o naslijeđu i tradiciji gledaoca današnjice. Slika perspektive predstavlja pogled na svijet po istom modelu kako to danas čine slike vladavine medija. Hans Belting taj pogled naziva „ikonični pogled”, a to je pogled koji postaje slika („zum Bild gewordener Blick"). Slika napada na WTC zahtijeva gledaoca jer postaje artikulirana tek u njegovom pogledu. Ona je rezultat "gladnog" oka savremenog gledaoca. Ovaj komunikacijski obrazac je znakovit jer „ono što kulture sa svojim slikama čine i na koji način svijet sažimaju u slike, vodi u suštinu njihovog promišljanja". ${ }^{14}$

Način na koji je predstavljen Feldmannov rad 9/12 Frontpage na izložbi Image Counter Image u centru Haus der Kunst u Minhenu 2012. godine, smjerno ukazuje na vizualnu agresivnost i slikomaničnost našega vremena. lako je to često potka Feldmannove umjetnosti, 9/12 Frontpage u svom formalnom aspektu posjeduje jednu lucidnu stranu koja se posredstvom svoje strukturalnosti referira na Mnemosyne Atlas Abyija Warburga ili na Imaginarni muzej Andréa Malrauxa. No, Feldamann kroz pojednostavljeni predložak jednog-teistog zapravo ironizira ogromno naslijeđe i baštinu vizualne kulture te je spušta na nivo ikonomanije i googlemanije novog doba. Preciznije, on ismijava simboličko preuveličavanje slike napadnutih tornjeva tako što u svojstvu forenzičara-detektiva na zidu pokušava rekonstruisati događaj kako bi pronašao počinitelja. Pritom na zid postavlja copy-paste sliku jednog prizora kako bi ukazao na banalnost industrije koja proizvodi, distribuiše, prodaje i manipuliše medijskim slikama današnjice.

U tom pravcu je korisno sagledati i interpretirati asamblaž belgijskog umjetnika Francisa Alÿsa Gun Camera iz 2005. godine koji pak aludira na proširene mogućnosti slikovne produkcije danas, osobito u kontekstu konflikta, sukoba i rata. Nastanak slika rušenja WTC-a, kao i njihov radikalni odnos naspram politike i historije, otvorio je političarima nove mogućnosti ratovanja. Pokrenuta je nova paradigma rata putem medija, pri čemu najsnažnije oružje predstavlja slika (Bilderkrieg). Alÿsov Gun Camera preuzima prepoznatljivi oblik kalašnjikova (AK-47), kojemu pak umjetnik dodaje videotraku kao simbol globalizirane medijske kulture. Umjetnik kreira višenamjensku spravu koja može da ubije i koja istovremeno bilježi, tj. dokumentira ubistvo kako bi zapis kasnije
The way in which Feldmann's 9/I2 Frontpage was presented at the exhibition Image Counter Image at Haus der Kunst in Munich (2012) intentionally revealed the visual aggressiveness and the iconomania of our times. Even though that is often the baseline of Feldmann's art, g/I2 Frontpage, formally speaking, had a lucid side to it, which referred in its structurality to the Mnemosyne Atlas by Aby Warburg or the Imaginary Museum by André Malraux. However, with his simplified model of one-and-the-same, Feldmann actually ironized the huge legacy and heritage of visual culture, reducing it to the level of iconomania and googlemania of modern times. More precisely, he mocked the symbolical exaggeration of the image of towers under attack, just like he tried to reconstruct the event on the wall in the role of a forensic detective in order to find the culprit. Thereby he copy-pasted a scene onto the wall in order to indicate the banality of an industry that produces, distributes, sells, and manipulates the media images of today.

This is the line along which one should also view and interpret the Gun Camera (2005), an assemblage by Belgian artist Francis Alÿs, which alludes to the extended options of modern visual production, particularly in the context of conflict, violence, and war. The creation of images showing the destruction of WTC and their radical relation to politics and history opened up new possibilities of warfare to the politicians. A new paradigm of war was launched through the media, with the image as its most powerful weapon (Bilderkrieg). Alÿs' Gun Camera takes on the recognizable form of a Kalashnikov (AK-47), to which the artist added a video-tape as a symbol of globalized media culture. Alÿs created a multifunctional device that could kill and document at the same time: it recorded a murder in order to reproduce and show it to the broader audience later on. The traumatic experience of the "Other" and its popularization through the electronic media went through a fundamental transformation after September II. Images such as the kneeling inmates of the Guantánamo prison or the obscure, naked bodies of Iraqi prisoners at Abu Ghraib are "signs of an altered conflict situation, a direct and active part of a new form of warfare." ${ }^{15}$ This work of Alÿs' thus combined two seemingly incompatible elements into a hybrid whole.

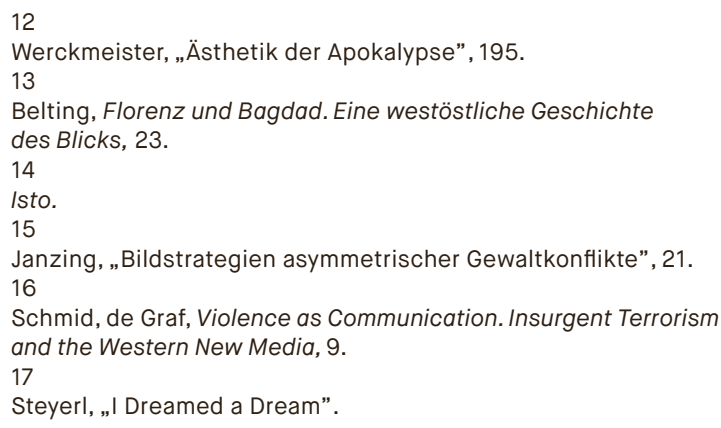


bio reproduciran i prikazan široj publici. Traumatsko iskustvo „drugog” i njegova popularizacija posredstvom elektronskih medija doživjelo je fundamentalnu transformaciju nakon 11. septembra. Slike kao što su klečeći zatočenici iz zatvora u Guantánamu, ili obskurna i obnažena tijela iračkih zatvorenika u Abu Ghraibu predstavljaju „znakove izmijenjene konfliktne situacije kao izravni i aktivni dio jedne nove forme vođenja rata". ${ }^{15}$ Ovaj Alÿsov rad spojio je, dakle, naizgled dva nespojiva elementa u jednu hibridnu cjelinu. $\mathrm{Na}$ simbiotički odnos nasilja i medija-kako je je to pošlo Alÿsu za rukom-ukazuju i teoretičari i historičari medija sa druge pozicije. Nasilje dobiva novi zamah zahvaljujući mogućnostima medija, a pronalazak dinamita i usavršenje rotacione štampe 1866. godine postaju „dva pronalaska koja su ubrzo počela da sarađuju”. ${ }^{16}$ Analogija između demokratizacije nasilja i demokratizacije medija je više nego očita. Berlinska videoumjetnica Hito Steyerl u svome predavanju održanom u Haus der Kulturen der Welt razrađuje odnose između pomenutih pronalazaka kroz teze o "demokratizaciji nasilja” i o „redukciji vještina” koje su postale potrebne za korištenje modernog vatrenog oružja, uzimajući pritom kao komparativni oslonac umjetnost evropske moderne. ${ }^{17}$ lako je njeno predavanje zamišljeno kao lecture-performance, Steyerl pronalazak revolvera poredi sa reproduktivnim tehnologijama reprezentacije i mogućnošću da sredstva za nastanak jednog umjetničkog djela postaju sve neznatnija, stavljajući u isti koš pritom Duchampov pisoar, Malevičev četvorougao, svijet reklama i masovni doprinos na YouTubeu.

15

Janzing, "Bildstrategien asymmetrischer Gewaltkonflikte," 2I. 16

Schmid, de Graf, Violence as Communication: Insurgent Terrorism and the Western News Media, 9.

17

Steyerl, "I Dreamed a Dream."

18

Jones, "The Lexicon of Offence: The Meanings of Torture,

Porn and 'Torture Porn',' I86-200.

19

Ibid., 187.
Theoreticians and historians of the media have also drawn attention to the symbiotic relationship between violence and the media - as successfully presented by Alÿs. Violence has gained a new momentum owing to the possibilities offered by the media, while the discovery of dynamite (I866) and the perfection of the rotary press were crucial, as "the two inventions soon started to interact." ${ }^{16}$ The analogy between the democratization of violence and the democratization of the media is more than obvious. In a lecture held at the Haus der Kulturen der Welt, Berlin-based video artist Hito Steyerl discussed the relations between the abovementioned inventions through her hypotheses on the "democratization of violence" and the "reduction of skills" needed to use modern firearms, taking European modern art as a basis for comparison. ${ }^{17}$ Even though her lecture was conceived as a lecture-performance, Steyerl has aptly compared the invention of the revolver with the reproductive technologies of representation and the possibility that the means for creating a work of art were becoming negligible, whereby she juxtaposed Duchamp's urinal, Mallevich's square, the world of advertising, and the massive proliferation of You Tube videos.

An indispensable reference in understanding and interpreting Alÿs' assemblage Gun Camera as an ingenious visual metaphor indicating the democratization of violence and documentary production are the media-produced images, namely documentary photographs and videos showing the dead enemies of the Western democracies: Saddam Hussein and Al-Zarqawi in 2006, and Osama Bin Laden and Muammar Gaddafi in 20II. Without questioning the credibility and authenticity of these images, it is obvious that their direct and explicit content speaks in the language of violence, in which the body plays the crucial role. It is about violence over the body, in which the subjected body, the wounded body, and the dead body are the formal content of the image. The political background of these images is the same, since their subjects were the offensive leaders of Arab (Muslim) countries. What unites them in terms of interpretation is the juxtaposition of opposing elements. Statesmen of the highest rank, political and military leaders, are here shown in a radically humiliating and degrading position. These images speak by means of their unexpected flow of events. Moreover, they address us with exceptional visual and psychological power and can thus be easily related to American film production and what the critics have termed "torture porn." ${ }^{18}$ The traumatic experience of others, be it staged on film or documented by amateur cameras as was the case with the said military leaders, it becomes popular and sought after, as such films present "non-sexual violence in such gory, close-up detail that their aesthetic is akin to pornography." 19 In case of politically motivated images (Hussein, Bin Laden, Gaddafi), the intensity further increases because they suggest the political reality, that is, the veracity of events, which enhances their effect. As such, these images are an immaterial monument to the successful politics of the Western allies and the defeat of the political "Other," in this 


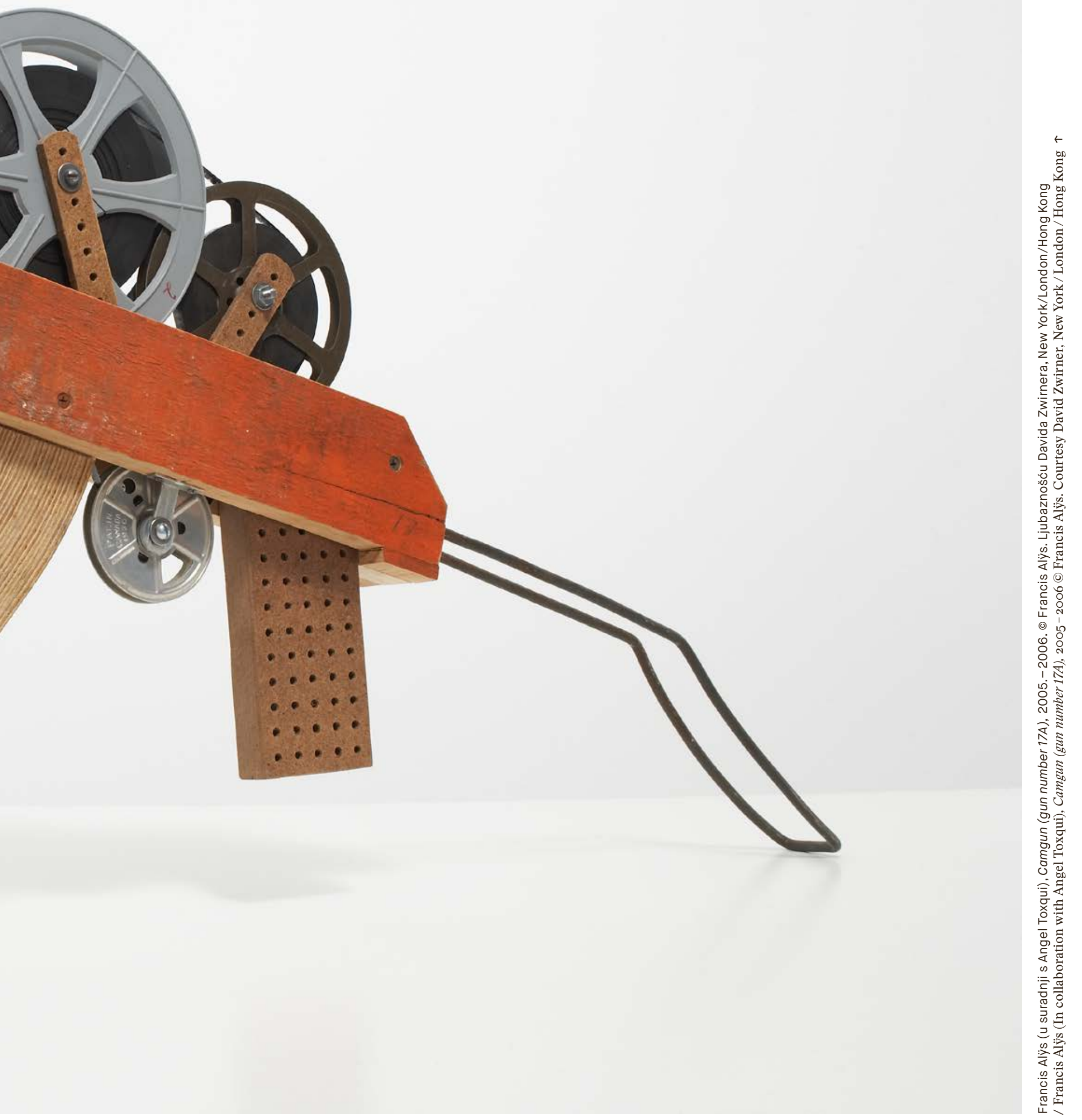
Neizostavna referenca u razumijevanju i interpretaciji Alÿsovog asamblaža Gun Camera, kao dosjetljive vizualne metafore koja ukazuje na demokratizaciju nasilja i dokumentaristike, jesu medijski proizvedene slike, tj. dokumentarna foto- i videografija ubijenih neprijatelja Zapadnih demokratija Sadama Huseina i Al Zarqawija 2006. te Osame Bin Ladena i Muamera Gadafija 2011. godine. Ne propitujući vjerodostojnost i autentičnost navedenih slika, one u svom izravnom i eksplicitnom sadržaju progovaraju jezikom nasilja pri čemu tijelo igra najbitniju ulogu. Radi se o nasilju nad tijelom u kojem podređeno tijelo, ranjeno tijelo i mrtvo tijelo čini formalni sadržaj slika. Navedene slike posjeduju istu političku pozadinu s obzirom na to da se radi o kompromitirajućim vođama arapskih, odnosno muslimanskih zemalja. Ono što ih objedinjuje u njihovom interpretativnom pogledu jeste jukstapozicija suprotstavljenih elemenata. Državnici najvišeg ranga, političke ili vojne vođe nalaze se u radikalno ponižavajućem i obeščašćujućem položaju. Te slike progovaraju strukturom neočekivanog razvoja događaja. Također, one posjeduju iznimno snažnu vizualnu i psihološku snagu te ih je lako dovesti u vezu sa američkom filmskom produkcijom i onim što je od kritičara nazvano „torture porn”. ${ }^{18}$ Traumatsko iskustvo drugih, bilo da je ekranizirano u filmu ili zabilježeno amaterskim kamerama, kao što je slučaj sa navedenim arapskim vođama, postaje popularno i traženo jer „krajnje krvavo predstavlja ne-seksualno nasilje uz eksplicitne detalje na način da su srodni pornografiji". ${ }^{19} \mathrm{U}$ slučaju političkih motiviranih slika (Hussein, Bin Laden, Gadafi) intenzitet se pojačava jer sugeriraju političku realnost, tj. istinitost događaja te u tom pogledu imaju snažniji učinak. Kao takve, navedene slike predstavljaju nematerijalni spomenik uspješnosti politike Zapadnih saveznika, tj. poraz političkog „drugog” koji je u ovom slučaju u medijima determiniran kao „islamski terorizam”. Nadalje, te slike zatvaraju krug od deset godina i funkcioniraju kao pandan slici rušenja njujorških tornjeva. Prva slika daje legitimitet razvoju događaja koji je zabilježen slikama ubijenih vođa. Takva vrsta komunikacije i klasifikacije ne bi bila moguća bez masovnih medija, jer „operirajući sa određenim ideološkim sistemom (bilo to tržište, socijalisti ili islamisti), radnici masovnih medija svjesno ili nesvjesno proizvode integrativnu propagandu koja služi sveobuhvatnim interesima elita". ${ }^{20}$ Slike koje nastaju u vremenu nakon 11 . septembra 2001. godine kao rezultat novinarskog izvještavanja sa terena progovaraju jezikom kulturalne, imperijalne, vojne i fizičke moći.

Okolnost da se zabijanje drugog aviona u južni toranj WTC-a prati uživo ponudila je gledaocima novi doživljaj u konzumaciji realnih konfliktnih sadržaja. Način, mogućnosti i učinak televizijskog izvještavanja sa Manhattana tog dana učinio je da se 11. septembar sa medijskog gledišta okarakterizira kao vrijeme televizije. „Po prvi put u historiji gledatelji na ekranima doživljavaju početak rata globalno i u najmanju ruku parcijalno u stvarnosti (in Echtzeit)". ${ }^{21}$ Direktan prijenos događaja, kao i njegova kasnija retrospektivna obrada dali su vizualnim medijima, osobito televiziji, novu ulogu. Primjenom digitalne tehnike reprodukcije case defined in the media as "Islamic terrorism." Moreover, these images close a circle of ten years and function as a counterpart to the image of destruction of the Twin Towers. The first legitimizes the course of events documented in the images of the assassinated leaders. This type of communication and classification would not be possible without the mass media. Since "operating within a particular ideological system (be it free market, socialist, or Islamist), mass media workers consciously or unconsciously produce integration propaganda that serves the overall interests of elites." ${ }^{20}$ Images produced after September II, 200I as a result of journalist coverage from the field speak in the language of cultural, imperial, military, and physical power.

The fact that the crashing of the second airplane into the southern WTC tower could be followed live offered to the spectators a new experience in consuming actual conflict-related content. The form, possibilities, and effect of television coverage from Manhattan that day led to September II being proclaimed, from the media point of view, as the era of television. "For the first time in history, TV audiences all over the world could experience the beginning of a war, and at least partially in real time (in Echtzeit)." ${ }^{21}$ Direct transmission of events, as well as its later, retrospective processing, gave a new role to the visual media, especially television. By employing digital technology in reproducing television image, the image of the terrorist act was intensified. This created a spectacular aesthetic fascination intended for the modern, demanding viewer. The effect of flashing sensation produced a pseudo-meaning that did not correspond to the reality.

An interpretation of CNN, an artwork of the Swiss artist Thomas Hirschhorn, is the best introduction into the multi-layered relations of the current socio-political situation. Hirschhorn has managed to attract the attention of art critics with his oeuvre focusing on the issues of shaping the public opinion, global politics, and consumerism, and his $C N N$ subverts the mainstream of political content, opening up new fields of interpretation. It is an object alluding at the cultic status of the media and their impact on our times, since television image and its live broadcasting have generated an entire new reality and paved the way for the subsequent political and military events.

18 Jones, „The Lexicom of Offence: The Meanings of Torture, Porn and 'Torture Porn'", 186-200. 19 Isto, 187. 20 Karim, „Making sense of the 'Islamic peril'. Journalism as cultural practice", 105. 21

Paul, Bilder des Krieges-Krieg der Bilder, 436. 
televizijske slike, slika terorističkog akta je intenzivirana. Stvorena je spektakularna estetska fascinacija namijenjena modernom i zahtjevnom gledaocu današnjice. Efektom blještave senzacije postignut je pseudoznačaj koji ne korespondira sa stvarnošću.

Čitanje rada švicarskog umjetnika Thomasa Hirschhorna CNN ponajbolje uvodi u slojevite relacije novonastale društvene i političke situacije. Kao umjetnik koji je kroz svoj opus uspio skrenuti pažnju kritičara sa radovima koji se bave pitanjima oblikovanja javnog mišljenja, globalne politike i konzumerizma, i njegov CNN subvertira glavne tokove političkih sadržaja i otvara nova interpretacijska polja. Radi se o objektu koji aludira na kultni status medija i njihov značaj u novom dobu, jer televizijska slika i njeno emitovanje uživo postaju generatori jedne nove stvarnosti koja je pogodovala razvoju političkih i vojnih događaja koji su uslijedili. Homogeniziran je nacionalni američki korpus; pokrenuta je globalna antiteroristička koalicija; otvoren je zloglasni zatvor u Guantanamu; stvoreni su uslovi za kontroverzne akcije saveznika diljem kugle. Pozlaćeni okovratni lanac sa zaštitnim znakom vodeće američke televizijske kuće CNN, kao simbolom američke globalne dominacije, propituje učinak moći posredstvom vladavine medija. Služeći se vokabularom modne industrije, lanac sa znakom CNN-a pokreće složena pitanja fetiša i kulta u neoliberalnom potrošačkom društvu aludirajući pritom na ulogu i značaj medija. Ovaj rad nastao je 2002. godine u vremenu najsnažnije ofanzive kada su se mediji-još pod dojmom napada na WTC-prepustili vodstvu američke administracije kao nezvanični glasnogovornici rata protiv terorizma. U tom Hirschhornovom radu eksplicitni akcenat nije stavljen samo na televizijsku kuću Cable News Network. Logotip CNN-a preuzima nova značenja te progovara o slojevitoj ulozi medija u današnjem svijetu suprotstavljenih i sukobljenih strana. Razvoj medijske prakse usmjerene ka senzaciji i blještavilu i invencija 24-satnog izvještavanja iz kriznih područja iz 1990-ih, poznatog kao „CNN efekat”, uspostavio je pozornicu za bombaše samoubice i anticipirao kolosalne terorističke napade kao što je to bio i napad na WTC.

20

Karim, "Making Sense of the 'Islamic Peril': Journalism as Cultural Practice," I05.

21

Paul, Bilder des Krieges - Krieg der Bilder, 436.
The American national corpus was homogenized and a global antiterrorist coalition launched; the notorious Guantánamo prison was established; the conditions were created for controversial actions by the allies all over the globe. The gilded necklace with the logo of the leading American television company $\mathrm{CNN}$, as a symbol of American world domination, questions the impact of power through the rule of the media. Using the vocabulary of global domination, the necklace with the CNN logo raises the complex issues of fetish and cult in the neoliberal consumerist society, alluding to the role and significance of the media. The artwork was produced in 2002, during the most powerful assault, when the media - still under the impression of the WTC attacks - succumbed to the American administration as the unofficial voice of war against terrorism. In Hirschhorn's work, the explicit accent is not only on the television house Cable News Network. The logo of CNN adopts here new meanings and speaks of the complex role of the media in the modern world of opposing and conflicting sides. The evolution of media practice, oriented towards sensation and flashiness, and the rg9os invention of 24 -hour media coverage from the areas of crisis, known as the CNN effect, created a stage for the suicide bombers and anticipated the massive terrorist attacks including the one on WTC.

The presence of American journalists at the frontline gave a fresh momentum to the media, but essentially it was a one-sided and incomplete coverage. On the other side of the frontline, there was no adequate media system that could continuously tell the story from the Arab perspective. In the newly created political constellation, the modern television house Al Jazeera was established, which launched a series of events commonly called "the $\mathrm{Al}$ Jazeera effect," implying the impact of the new media and sources on global politics and the reduction of the informational monopoly of governments and news agencies. As a nominally Arab television house, Al Jazeera intensified the bipolarity between East and West, which remained present after September II, 200I. Besides their role as the catalysts of field reporting, these two television houses, $\mathrm{CNN}$ and Al Jazeera, can be interpreted as a metaphor of the newly created geo-political relations, which acquired a proper form some two decades after the demolition of WTC. In this context, a counterpart of Hirschorn's CNN may be the artwork Al Jazeera by the Moroccan artist Mounir Fatmi. Using an antenna cable and the corresponding fasteners, Fatmi reconstructed the logo of Al Jazeera as a drawing. The work is complex and requires a broad field of interpretation. Regarding the fact that the logo of the television house was done in calligraphy, which carries sacral meanings in the Arab-Islamic context, the artist juxtaposed the calligraphic tradition of Arab provenance and the achievements of modernity, raising some topical issues on Arab animosity towards novelty, progress, and invention. In that sense, he deconstructed the established image of Arab identity as something fixed and tradition-bound. 
Prisustvo američkih novinara na prvoj liniji fronte dalo je medijima novu dinamiku, ali u suštini je došlo do jednostranog i nepotpunog izvještavanja sa terena. Sa druge strane borbene linije nije postojao adekvatan medijski sistem koji bi u kontinuitetu prikazivao priču iz arapske perspektive. U novonastaloj političkoj konstelaciji formirana je moderna televizijska kuća Al Jazeera koja je pokrenula niz događaja stručno nazvanih „Al Jazeera efekat”, što pak označava utjecaj novih medija i medijskih izvora na globalnu politiku i smanjenje informativnog monopola vlada i novinskih agencija. Kao nominalno arapska televizijska kuća, Al Jazeera je pojačala bipolarnu suprotstavljenost na relaciji istok-zapad, što je ostalo naglašeno poslije 11. septembra 2001. godine. Osim što postaju katalizatori izvještavanja sa lica mjesta, imena dviju televizijskih kuća, CNN-a i Al Jazeerae, moguće je tumačiti kao metaforu novonastalog geopolitičkog odnosa čiji obrisi gotovo dvije decenije nakon rušenja WTC-a poprimaju svoj konkretan oblik. U tom kontekstu, Hirschornovom radu CNN kao pandan je moguće staviti rad Al Jazeera marokanskog umjetnika Mounira Fatmija. Koristeći antenski kabl i uz njega pripadajuće pričvršćivače, Fatmi u vidu crteža rekonstruiše oblik logotipa arapske televizijske kuće Al Jazeere. Rad je slojevit i podrazumijeva široko interpretativno polje.S obzirom na to da je sâm znak ove televizijske kuće realiziran umijećem lijepog pisanja koje u arapsko-islamskom kontekstu implicira sakralna značenja, umjetnik kaligrafsku tradiciju arapske provenijencije suočava s dostignućima modernizma i time otvara neka recentna pitanja o arapskom animozitetu prema novom, naprednom i inventivnom. Utoliko, Fatmi u svom radu dekonstruiše uvriježenu sliku arapskog identiteta kao nečeg fiksnog i uslovljenog tradicijom.

Kooptacija logotipa novinskih kuća od strane umjetnosti, iako ciničan, čin je koji ukazuje na novu moć savremenih medija da posredstvom posve nove tehnologije sliku običnog događaja konvertira u svojevrsnu ikonu, tj. znak. Način reproduciranja takvih slika, metrike njihovog emitovanja i naknadne interpretacije omogućilo je kreiranje znakovitih slika-preciznije signs, kako ih elaborira historičar umjetnosti i teoretičar slike Horst Bredekamp. Njihov zadatak je gotovo misionarski-da mijenjaju „političke retorike, vodeći u konačnici ka reherojizaciji rata”. ${ }^{22}$ Teza da je „materijalna katastrofa u New Yorku anticipirana medijski insceniranom katastrofom" sugerira da su nove tehnološke mogućnosti odredile novi karakter i obim nasilja, a time i konstituciju njihovog slikovnog uprizorenja. ${ }^{23}$

Interpretacija i razumijevanje radova umjetnika kao što su Hans Peter Feldmann, Doug Ashford, Francis Alÿs, Thomas Hirshhorn i Mounir Fatmi moguća je upravo unutar teoretskog okvira kojeg su zadali vodeći stručnjaci na polju teorije medija a baveći se globalnim ratom protiv terorizma poslije 11. septembra 2001. godine. Nova dinamika medija sa posve novom slikovnom politikom-unutar koje su inicirana i pitanja o slobodi izražavanja, demokratiji, medijskoj etici, ali i pitanja odnosa istine i laži-poslužili su umjetnicima kao polazište za djelovanje. Stoga pomenute radove i njihovo javno prikazivanje treba razumjeti i kao političku gestu-u
The co-optation of the logo of news agencies by artists, even though cynical, indicates the new power of the contemporary media to convert an image of an ordinary event into a sort of icon or sign by using the latest technologies. The way of reproducing such images, the dynamics of their broadcasting, and their subsequent interpretation have made it possible to create symbolical images - or rather signs as elaborated by the art historian and image theoretician Horst Bredekamp. Their task is almost missionary - they are expected to change "the political rhetoric, eventually leading to a re-heroicization of war." ${ }^{22}$ The hypothesis that "the material catastrophe in New York was anticipated by a catastrophe staged by the media" suggests that the new technological possibilities have determined the new character and scope of violence, and thus the constitution of their visual enactment. ${ }^{23}$

Interpreting and understanding works of artists such as Hans Peter Feldmann, Doug Ashford, Francis Alÿs, Thomas Hirshhorn, or Mounir Fatmi is possible precisely owing to the new theoretical framework, construed by the leading experts in the field of media theory when dealing with the global war against terrorism following September II, 200I. The new dynamism of the media, with an entirely new visual policy - within which issues of the freedom of speech, democracy, media ethics, as well as truth vs. lies could be raised-has served these artists as a starting point. For this reason, the said artworks and their public presentation should also be understood as a political gesture - in the era of political hegemonization of the "Western bloc" in its war against terrorism, they have been deconstructing, criticizing, and mocking the content of such politics.

22

Bredekamp, „Handeln im Symbolischen”, 6. 23

Isto.

24

Mitchell, „Madness and montage: The Picture Atlas as symptom and Therapy from Aby Warburg to A Beautiful Mind". 25

Ovaj rad nastao je u sklopu postdoktorskog istraživačkog boravka na Univerzitetu u Gentu (Belgija) 2013/2014. godine u okviru istraživačkog projekta „Portraying the 'Other':

Terrorism and Contemporary Art after 11/9", a njegovi različiti aspekti u nešto izmijenjenim oblicima bili su oralno predstavljeni na međunarodnim interdisciplinarnim simpozijima „Filozofija medija: Umjetnost i mediji” u Opatiji septembra 2012. i „Estetika brutalnosti. Događaji i slike poslije 11/9" u Bihaću marta 2016. godine. 
vremenu političke hegemonizacije „zapadnog bloka” u ratu protiv terorizma oni dekonstruišu, kritikuju i ismijavaju sadržaje takve politike. Kao takvi, navedeni radovi smjerno subvertiraju ikoničnost hipertrofiranih medijskih slika, a njihovu vjerodostojnost dovode u pitanje. Konstatacija znamenitog slikovnog teoretičara W. J. T. Mitchella da je „na početku fotografske revolucije, fotografija bila nosilac apsolutne istine, dok je danas nosilac sumnje i laži”, ${ }^{24}$ čini se kao idealna podloga za optiku koja u fokus uzima preklapanja umjetnosti i medija u eri poslije napada na WTC. ${ }^{25}$

.
In this way, they have intentionally subverted the iconic nature of hypertrophied images in the media, questioning their credibility. The conclusion of the renowned visual theoretician W.J.T. Mitchell that at the beginnings of photographic revolution, photography was the bearer of absolute truth, whereas today it is the bearer of scepticism and lies, ${ }^{24}$ seems like an ideal basis for a perspective that focuses on the overlapping between art and the media in the age following the WTC attacks. ${ }^{25}$
22

Bredekamp, "Handeln im Symbolischen," 6.

23

Ibidem.

Mitchell, "Madness and Montage: The Picture Atlas as Symptom and Therapy from Aby Warburg to A Beautiful Mind."

25

Research for this study was conducted during my postdoctoral residence at the University of Gent (20I3/2OI4) as part of the project "Portraying the 'Other': Terrorism and Contemporary Art after II/9," with various aspects (in somewhat altered forms) orally presented at the international interdisciplinary conferences "Filozofija medija: Umjetnost i mediji" [The philosophy of the media: Art and the media] in Opatija (September 20I2) and "Estetika brutalnosti. Događaji i slike poslije II/9" [The aesthetics of brutality: Events and images after 9/II] in Bihać (March 20I6). 


\section{POPIS LITERATURE / BIBLIOGRAPHY}

Belting, Hans. Florenz und Bagdad. Eine westöstliche Geschichte des Blicks. München: C. H. Beck, 2008.

Bredekamp, Horst. „Handeln im Symbolischen”. Kritische Berichte 1 (2005): 5-10.

Bush, George. „Address to a Joint Session of Congress and the American People". The White House. President George W. Bush. http://georgewbush-whitehouse.archives.gov/news/ releases/2001/09/20010920-8.html (pristupljeno 2. februara 2018./last accessed on February 2, 2018).

Carey, James W. „American journalism on, before, and after September 11”, 85-103. U/In: Journalism after September 11, ur./ed. Barbie Zelizer, Stuart Allan. London-New York: Routledge, 2003.

Gehring, Ulrike. „Der Angriff auf das singuläre Bild”. Kritische Berichte 1 (2005): 12-20.

Hess, Stephen, Kalb, Marvin, ur./ed. The Media and the War on Terrorism. Washington: Brooking Institution Press, 2003.

Janzing, Godehard. „Bildstrategien asymmetrischer Gewaltkonflikte". Kritische Berichte 1 (2005): 21-35.

Jones, Steve. „The Lexicom of Offence: The Meanings of Torture, Porn, and 'Torture Porn'”, 186-200. U/In: Controversial Images. Media Representatins on the Edge, ur./ed. Feona Attwood, Vincent Campbell, I. Q. Hunter, Sharon Lockyer. London- New York: Palgrave Macmillan, 2013.

Karim, Karim H. „Making sense of the 'Islamic peril'. Journalism as cultural practice”, 101-116. U/In: Journalism after September 11, ur./ed. Barbie Zelizer i Stuart Allan. London-New York: Routledge, 2003.

Mitchell, William John Thomas. „Madness and Montage: The Picture Atlas as Symptom and Therapy from Aby Warburg to A Beautiful Mind". Oralno predavanje na konferenciji/Conference paper: Image operations, ur./ed. Charlotte Klonk, Jens Eder. ICI Berlin Institute for Cultural Inquiry, 2014.

Paul, Gerhard. Bilder des Krieges-Krieg der Bilder. München: Ferdinand Schöningh - Wilhelm Fink, 2004.

Schmid, A., de Graf, J. Violence as Communication. Insurgent Terrorism and the Western News Media. London-Beverly Hills: Sage, 1982.

Schmitt, Axel. „Die Weisse Magie des Kinos und die schwarze Magie des Terrorismus". U/In: Literaturkritik.de. www.literaturkritik.de/public/rezension.php?rez_id=5336 (pristupljeno 2. februara 2018./last accessed on February 2, 2018).

Simon, Joshua. „Thoughts on the Aesthetics of Terror in General and Suicide Bombers' Videos in Particular”, 38-47. U/In: The Aesthetics of Terror, ur. Manon Slome, Joshua Simon. Milano: Charta, 2009.

Sreberny, Annabelle. „Trauma talk”, 220-234. U/In: Journalism after September 11, ur./ed. Barbie Zelizer, Stuart Allan. London-New York: Routledge, 2003.

Steyerl, Hito, „I Dreamed a Dream”. Predavanje održano u Haus der Kulturen der Welt/lecture held at the Haus der Kulturen der Welt, Berlin, 2013.

Stockhausen, Karlheinz. „Huuuh!”. Stockhausen.org, 2001. http://www.stockhausen.org/hamburg.pdf (pristupljeno 2. februara 2018./ last accessed on February 2, 2018).

Weiman, Gabriel, Winn, Conrad. The Theater of Terror. Mass Media and International Terrorism. New York: AddisonWesley Longman Ltd, 1994.
Werckmeister, Otto Karl. „Ästhetik der Apokalypse”, 195-207. U/In: Kunst + Krieg, ur./ed. Bazon Brock, Gerline Koschik. München: Wilhelm Fink Verlag, 2008.

Žižek, Slavoj. „Willkommen in der Wüste des Realen”, 57-65. U/In: Kunst nach Ground Zero, ur./ed. Heinz Peter Schwerfel. Köln: Dumont, 2002.

Welcome to the Desert of the Real! Five Essays on

September 11 and Related Dates. London - New York: Verso, 2002. 
